\title{
COVID 19: Un nou món per construir, una nova societat per desco- brir
}

\author{
Jordi Brasó i Rius (Universitat de Barcelona)
}

Žižek, S. (2020) Pandèmia. La covid-19 trasbalsa el món.

Barcelona, Anagrama, 120 pàgs.

Tot i tractar el principal tema d'actualitat, és a dir, la pandèmia actual de la COVID $2019 \mathrm{i}$ els seus efectes a la societat, el filòsof i pensador eslovè Slavoj Žižek proposa una anàlisi del món i una mirada crítica cap a un futur que canviarà la societat actual (Amadeo, 2020a; Amadeo, 2020b; Salinas, 2020). De fet com a collectiu ja hem experimentat canvis que només imaginàvem en somnis i en pel.lícules futuristes. Així, l'aillament dins les llars -els qui en tenen- $\mathrm{i}$ les ciutats deshabitades han estat mètodes de protecció però que alhora han agreujat les diferències entre rics i pobres, i que fan repensar tot el model de convivència social. Si abans de la pandèmia les diferències d'estatus eren desorbitades, ara encara ho són més.

En aquesta idea, les noves maneres comunicatives i de relacions socials, familiars, laborals... a partir dels dispositius mòbils han alterat les relacions entre individus però també han implicat noves maneres d'actuació i nous canvis de vida. Ara estem encara més connectats que mai, però també més separats físicament dels altres. Com a conseqüència de tot plegat, la tecnologia també ha incrementat aquestes diferències socials.

Aquests canvis, apunta Žižek impliquen que «no hi haurà cap retorn a la normalitat» $(2020$, p. 12). Sembla així, una mirada incerta, preocupant i pessimista, tot $\mathrm{i}$ que la lectura del llibre Pandèmia. La covid19 trasbalsa el món (2020), publicat per l'editorial Anagrama ens ofereix també una possible visió motivadora i expectant, en una idea d'un nou futur que vindrà $i$ que caldrà construir. Serà, per tant, el ciutadà i el nou model polític i econòmic que pugui sorgir el qui determinarà aquesta nova manera de relacionar-nos, de treballar, de consumir, d'oci... i, en definitiva, de viure. Caldrà així dur a terme iniciatives de collaboració i iniciativa popular com diria Oliveres (2021).

Žižek es fixa en un element clau per superar la crisi: «la confiança mútua entre la gent $i$ els aparells de l'estat» (p. 19). És un fet clau i ben probablement somiador, en una societat en la qual no existeix aquest element de confiança i que, tot sigui dit, sembla que no hi serà, almenys a curt termini. La gestió de la crisi, les incongruències en les accions del govern, les justificacions i normatives a última hora, etc. no permeten albirar un futur en el qual Estat $i$ el ciutadà es facin confiança mútua. I a aquest fet se li afegeix l'actual sistema neoliberal que s'imposa, de poder per les grans empreses $i$ en el qual s'ha aconseguit una màxima explotació del treballador. La causa és que la (bio)política de l'Estat ha impedit afavorir un dret bàsic del ciutadà com és el de la qualitat laboral (Foucault, 2012) De tota manera, Žižek fa veure que, al cap i a la fi, que «tothom és un treballador autoexplotat de la seva pròpia empresa» (p. 24). Fa reflexionar aquest pensament, i podríem autoanalitzar-nos si, 
a part del sistema imposat, nosaltres mateixos ens hem endinsat i acceptat una societat que viu per treballar únicament.

Una altra qüestió a tenir en compte és el control que ha aparegut arran de la pandèmia de coronavirus. S'ha legitimat tot un sistema en el qual la restricció de llibertat sembla que augmenta cada dia una mica més. Slavoj Žižek proposa una societat alternativa (p. 41) i intueix i veu com a possible una solidaritat global i de cooperació (p. 42). Mostra inclús exemples succeïts relacionats amb aquest fet. Proposa així, reorganitzar l'economia mundial per evitar aquesta societat neoliberal que perjudica, al cap i a la fi, als drets i a la qualitat de vida del ciutadà. També fa èmfasi en una societat que cada vegada és més digital (Sacristán, 2018). Sembla així que la realitat (única), ara ja sí, és la virtual. I en aquesta societat virtual, en la qual el filòsof comenta que també hi ha virus, apareix la xarxa d'Internet i el telèfon, dos instruments controlats pels grans poders: tot queda controlat, restringit. Pel que fa al virus, i relacionant-ho amb aquesta aparició als mitjans de comunicació, l'autor també fa una crítica a la percepció dels individus que tenen de la pandèmia. I és que la importància que se li dona a les xarxes socials, anuncis, diaris —ara digitals_-... fa reflexionar sobre l'objectiu real i amagat dels mitjans de comunicació, dels polítics, dels grups de poder. Apareixen amb una gran força tots aquells aparells ideològics de I'Estat com diria Althusser (1987) del capitalisme agressiu. Unes preguntes per a la reflexió serien les següents: Quin és el sentit i motiu d'aquest excés d'informació? Per què se'ns vol fer tanta por? Així mateix, Žižek es pregunta «Com és que els mitjans i les autoritats fan tot el que poden per crear un clima de pànic [...]?» (p. 74). Amb exemples, I'autor, mostra altres situacions de la societat en les quals la quantitat de víctimes són majors, però en aquest cas, ni s'acaba informant ni divulgant i, per suposat, ni interessa fer-nos por. Sembla així que l'epidèmia és «el pretext ideal» per crear un estat de pànic (p. 75).

Fa pensar tot plegat en tot aquest conjunt de notícies i informacions que constantment es reben de manera distorsionada, seccionada i que veiem com a la nostra realitat. Aquest fet, a més, s'incrementaria amb el fenomen del big data, en el qual rebríem les informacions que el sistema vol que rebem segons la nostra manera de ser i actuar. Es generen així notícies segons les nostres idees, visualitzem anuncis segons els nostres pensaments $i$ criteris de consum $i$, en general, es crea un món virtual, fals, a la mida del client-ciutadà. Per tant, tota aquesta tecnologia, que al cap i a la fi és un simple instrument caldrà utilitzar-la de manera conscient, reflexiva i crítica (Garcés, 2017).

Amb tot, l'autor reflexiona així si un dels objectius que es busquen amb la pandèmia és limitar i controlar la llibertat, a mode de la societat xinesa, a dia d'avui. Aquest fet caldrà tenir-lo en compte en els diversos àmbits, també en l'aspecte pedagògic. Per tant, caldrà analitzar com afectarà tot aquest nou model social a les escoles, instituts, universitats i buscar una mirada crítica en favor del ciutadà. Quin serà el nou paper del docent? Caldrà la figura del mestre? Quins avantatges tindrà una educació amb docència i un autoaprenentatge a través de la xarxa i el coneixement que hi ha immers? (Brasó, Torrebadella, 2018; Garcés, 2017; Girón, 2020; Sousa, 2020)

Per acabar Žižek comenta que l'afectació del virus esdevé de manera triple, en tres àmbits: mèdic, econòmic, psicològic. I caldrà pensar en l'esforç per construir aquesta nova humanitat futura que s'uneix per un objectiu comú, en favor de 
les persones. Això sí, cal pensar en un nou futur, en una era virtual, ens agradi o no.

\section{Referències}

Althusser, L. (1987) Ideología y aparatos ideológicos del estado. México, Quinto Sol.

Amadeo, P. (ed.) (2020a) La fiebre. Buenos Aires, ASPO (Aislamiento Social Preventivo Obligatorio).

Amadeo, P. (ed.) (2020b) Sopa de Wuhan. Buenos Aires, ASPO (Aislamiento Social Preventivo Obligatorio).

Brasó, J.; Torrebadella, X. (2018) «Reflexiones para (re)formular una educación física crítica». Revista Internacional de Medicina y Ciencias de la Actividad Física y el Deporte, 18 (71), p. 441-462. doi: http://dx.doi.org/10.15366/rimcafd20 18.71 .003

Foucault, M. (2012) Nacimiento de la biopolítica. Madrid, Akal.

Garcés, M. (2017) Nova il.lustració radical. Barcelona, Anagrama.

Girón, J. (ed.) (2020) Educación y pandemia. Una visión académica. México, UNAM.

Oliveres, A. (2021) Paraules d'Arcadi. Què hem après del món i com podem actuar. Barcelona, Angle.

Sacristán, A. (2018) Sociedad digital, tecnológica y educación. Madrid, Uned.

Salinas, J. (2020) Covid-19. Hacia la nueva normalidad. Murcia, Malbec.

Sousa, B. (2020) La cruel pedagogía del virus. Buenos Aires, Clasco. 